\title{
Violence against Women: Exploring Discursive Resistance in the Frames of Gender Violence in South Africa
}

\author{
Kunle Oparinde, Rachel Matteau-Matsha and Felix Awung \\ Department of Media, Language and Communication, Faculty of Arts and Design \\ Durban University of Technology, South Africa
}

\begin{abstract}
In recent times, the issue of gender-based violence against women in South Africa is prevalent in headlines due to the high rate of attacks directed towards women. Ranging from teenagers to adults, women are continuously targeted indiscriminately in what is seemingly becoming a prolonged cycle in the country. To this end, human right activists, organisations and political leaders have managed to somewhat verbally condemn the atrocious acts. Further, interested people in South Africa, through walks and protests, have continued to speak against the swinging violence against women in the country. The thrust in this study is to explore and analyse how discourse (language) has been employed as a resounding voice against gender violence in the country. Through a purposive sampling of materials employed during walks and protests, collected from online sources, we examine how language is being used to combat and confront the issue of gender violence viz-a-viz how it continue to serve as a crucial tool in repelling gender violence.
\end{abstract}

Keywords: gender, violence, language, discourse, resistance 